\title{
Utility of tissue microarrays MIB-1 for profiling prognostic biomarkers in clinically localized prostate cancer
}

Primeira submissão em 04/06/09 Última submissão em 07/06/09 Aceito para publicação em 18/12/09 Publicado em 20/10/09

\section{Expressão imuno-histoquímica do MIB-1 como fator prognóstico em pacientes com adenocarcinoma de próstata localizado}

Aissar Eduardo Nassif'; Renato Tambara Filho²; Regina Xavier Gomes De Paula ${ }^{3}$

key words
Prostatectomy
Prostate neoplasm
MIB-1 antibody

MIB-1 antibody

\section{abstract}

Introduction and objective: To analyze the immuno-histochemical expression of MIB-1 marker as a prognostic factor in patients with localized prostate neoplasia. Methods: Analysis of 100 cases of patients with localized prostate neoplasia who underwent curative surgery from January 2000 to December 2006. The customary histological preparation was carried out, followed by immunohistochemical reaction to detect MIB-1 protein accumulation and statistical analysis. Results: There was a larger proportion of negative expression for MIB-1 marker $(63.0 \%, p<0.0001)$. Patients with positive expression (MIB-1 positive) had higher PSA (PSA $\geq 10 \mathrm{ng} / \mathrm{dl})(p=0.010)$, higher Gleason score $(\geq 7)(p=0.0003)$ and pathological stage $\mathrm{pT} 2 \mathrm{c}(p=0.001)$. In the comparison of variables, it was noticed that patients with positive expression had a higher mean PSA $(p=0.031)$, higher Gleason score $(p<0.0001)$, longer follow-up $(p=0.037)$, larger area of vascular proliferation $(p<0.0001)$ and higher proportion of tumor in relation to normal area $(p=0.012)$. Conclusion: MIB-1 proved to be a prognostic factor comparable to PSA, Gleason and staging.

\section{resumo}

Introdução e objetivo: Analisar a expressão imuno-histoquímica do marcador MIB-1 como fator prognóstico em pacientes com neoplasia de próstata localizada. Métodos: Análise de cem casos de pacientes portadores de neoplasia prostática localizada submetida a cirurgia curativa no período de janeiro de 2000 a dezembro de 2006. Realizou-se o preparo histológico habitual seguido de reação imuno-histoquímica para a detecção do acúmulo da proteína MIB-1 e análise estatística. Resultados: Obteve-se maior proporção de expressão negativa ao marcador MIB-1(63\%, $\mathrm{p}<0,0001)$. Os pacientes com expressão positiva (MIB1 positivo) apresentaram antígeno prostático específico (PSA) mais elevado (PSA \&\#8805;10 ng/dl) $(p=0,01)$, escore de Gleason mais alto $(\& \# 8805 ; 7)(\mathrm{p}=0,0003)$ e estádio patológico $\mathrm{pT2c}(\mathrm{p}=0,001)$. Na comparação das variáveis observou-se que os pacientes com expressão positiva apresentaram PSA médio mais elevado ( $\mathrm{p}$ $=0,031)$, escore de Gleason mais alto $(p<0,0001)$, maior tempo de seguimento $(p=0,037)$, maior área de proliferação vascular $(\mathrm{p}<0,0001)$ e maior proporção de tumor em relação à área normal $(\mathrm{p}=0,012)$. Conclusão: O MIB-1 mostrou-se um fator prognóstico comparável a PSA, Gleason e estádio. unitermos

Prostatectomia

Neoplasia de próstata

Anticorpo MIB-1

1. Doutor; ex-aluno do programa de pós-graduação em Clínica Cirúrgica do Hospital de Clíncias da Universidade Federal do Paraná (UFPR); professor adjunto da Unidade de Ensino Superior Ingá Ltda. (UNINGÁ).

2. Doutor; livre-docente; professor adjunto de Urologia da UFPR.

3. Doutora; patologista do Serviço de Urologia da UFPR.

Suporte financeiro: Coordenação de Aperfeiçoamento de Pessoal de Nível Superior (CAPES) e Conselho Nacional de Desenvolvimento Científico e Tecnológico (CNPq). 


\section{Introduction}

The prostate cancer is the most common malign visceral neoplasia in men and the incidence tends to increase in coming decades with the increase in life expectancy ${ }^{(14,24,37)}$. Approximately 543 thousand new cases are diagnosed each year worldwide. In Brazil, the National Cancer Institute predicted 49,530 new cases in 2008, a number that corresponds to an estimated risk of 52 new cases for every 100 thousand men, being the most common not skin tumor more often in all regions of the country ${ }^{(21)}$.

Despite the gain of epidemiological and bimolecular knowledge of prostate cancer, it cannot predict which patients will develop clinically significant disease and which will remain with tumor confined ${ }^{(23,28,34)}$.

In prostatic cancer, the histopathological analysis has great clinical relevance ${ }^{(5,25)}$. Histological and serological exams describe very important aspects, allowing the monitoring of the disease evolution $^{(3,16)}$. However, the immuno-histochemical methods as discussed in qualitative form have shown great disparity and variability of results among different observers ${ }^{(13,14,30)}$. In order to provide a numerical scale and reproducible patterns of marking tissue, increasing the sensitivity and quality control analysis, it has sought increasingly technological refinements using automated morphometric methods ${ }^{(12)}$.

The search for an ideal prognostic factor of cancer of the prostate, including the decision to allow the patient about the type of treatment to choose, has been one of the great challenges in medicine. When we identify the biological variables that help in the indication of adjuvant therapy, we probably reduce the rates of tumor recurrence ${ }^{(10,19,22,26)}$. Many studies have demonstrated the importance of new immunohistochemical markers that may in future be used as predictors of prognosis and development of tumors ${ }^{(13,16)}$.

\section{Methods}

This study was approved by the Research Ethics Committee in Human Beings in the HC-UFPR and it is in accordance with national and international current rules (Res. 196/96 CNS-MS and other resolutions).

\section{Characterization of the sample}

It was studied 100 cases of patients with prostate cancer submitted to the radical prostatectomy and pelvic lymphadenectomy in the period of January 2000 to December 2006.

All patients in the study were diagnosed with adenocarcinoma of the prostate, acinar usual type, with preoperative clinical stage of T1c and T2c. The clinical history, general physical examination, and urological and laboratory tests (general and specific haematological evaluation with PSA) were systematically analyzed by the same observer.

The evaluation of transrectal ultrasound and biopsy of the achievement were made by the same professional. A transrectal biopsy was performed on a larger way with side region samples and the transition zone with 12 or 14 samples. The patients underwent tests for preoperative staging with bone scintigraphy, chest X-rays and $\mathrm{CT}$ or MRI of pelvis, according to the necessity. The patients were staged according to the latest update proposed by the International Union against Cancer, TNM. After confirmation of diagnosis by biopsy, there was in interval of 4 to 6 weeks for surgery. The surgical specimens were taken and analyzed in the same laboratory and these blocks and reports were reviewed by an uropathologist.

\section{Histological processing}

The surgical specimens were submitted to serial sections, comprehending slices with $0.5 \mathrm{~cm}$ thick throughout the gland, and obeying the routine and the protocol. The material was embedded in previously Indian ink for better identification and assessment of surgical margins. The slices representing macroscopic cuttings with rotary microtome (American Optical Instruments ${ }^{\circledR}$ ) were submitted to the inclusion in paraffin to make histological sections of $3 \mu \mathrm{m}$ thick and stained with hematoxylin-eosin. Once established the diagnosis by the pathologist, they were separated from the paraffin blocks of tumor areas to be studied.

The slide with the best representation of the tumor was selected for immunohistochemical study. The microscope used for the study was a Nikon ${ }^{\circledast}$ brand, model Eclipse E-400. All slides were evaluated by the same uropathologist. 


\section{Coloring immuno-histochemical and microscopic evaluation}

Histological staging was established according to the criteria of Gleason. The immuno-histochemical reaction was used to detect the accumulation of MIB-1 protein. Histological sections were rewashed and hydrated in decreasing concentrations of ethanol and washed in distilled water. The material was placed in a solution of citrate $(\mathrm{pH}$ 6) and led to a microwave oven on medium-maximum temperature for 15 minutes, after being removed and left to stand at room temperature for 15 minutes. After adding the material on a PBS buffer solution ( $\mathrm{pH}=7.6$ ) was used to block the endogenous peroxidase, the slices were incubated in a solution of $3 \%$ hydrogen peroxide in methanol for 30 minutes at room temperature.

Then, proceed a cycle of washing with distilled water and the material was incubated for 30 minutes in a solution containing $4 \%$ normal serum in PBS. The specific antibody (DO-7, Dako A/S, Denmark) were prepared at a 1:50 dilution in PBS and incubated with the sections for 12 hours in a moist chamber. After a new cycle of washes, the sections were again placed in a moist chamber for incubation for 30 minutes with the secondary antibody of biotinylated anti-mouse IgG (Vectastain, Vector Lab, CA, USA) diluted 1:600 in PBS. After another round of washes, the material was incubated in a moist chamber for 60 minutes with the complex avidin/biotin (Streptococcus $A B C$, Vectastain, Vector Lab CA, USA) with dilution 1:800 in PBS. The color of the immunoperoxidase reaction was performed by immersion, for 8 minutes in a solution containing the chromogen DAB (tetra-hydrochloride 3,5-diamino-benzidine) and hydrogen peroxide. After washing in running water, it was held against the staining with Harris hematoxylin (Merck, Darmstadt, Germany) for 2 minutes.

Each group of sections was subjected to analysis included positive and negative controls. The reading of the reaction was made in light microscope and was observed the criteria for positivity used by other authors, or a minimum percentage of $5 \%$ of cells stained by a large field increase (400x).

\section{Statistical analysis}

The descriptive analysis of data used tables and graphs. For the proof of the objective of this work it was used parametric tests $t$ Student and the non-parametric Mann-
Whitney, comparison between two proportions (using the software Primer of Biostatistics), chi-square and Fishers exact (the Epi-Info). The significance level (probability of significance) adopted was less than $5 \%(p<0.05)$.

\section{Results}

With the marker MIB-1 it was observed, in general, a greater proportion of negative expression (63\%) $(p<0.0001)$ (Table 1).

\section{Table 1 Expression of the marker MIB-1}

\begin{tabular}{lcc}
\hline Expression & Number & Percentage \\
Negative & 63 & 63 \\
Positive & 37 & 37 \\
Total & 100 & 100
\end{tabular}

$p<0.0001$ (proportion)

For the patients with positive expression (MIB1 positive), it was observed higher PSA (PSA $\geq 10 \mathrm{ng} / \mathrm{dl})(p=0.01)$, higher Gleason score $(\geq 7)(p=0.0003)$, pathological stage $\mathrm{pT} 2 \mathrm{c}(p=0.001)$ and greater proportion of impotent patients $(p=0.086)$ (probability borderline, indicating a tendency) (Table 2).

In the comparison of variables, regarding the marker MIB1 it was observed that patients with positive expression (MIB1 positive) also had a higher medium PSA $(p=0.031)$, higher Gleason score $(p<0.0001)$, longer follow-up ( $p=0.037)$; largest vascular proliferation $(p<0.0001)$ and higher proportion of tumor area in relation to normal $(p=0.012)$ (Table 2).

\section{Discussion}

The Ki-67 is one of the several cell cycle regulatory proteins that can be analyzed by immunohistochemistry, being the MIB-1 a monoclonal antibody developed against the antigen $\mathrm{Ki}-67^{(8,18)}$. It is a DNA binding protein that is expressed in all phases of the cell cycle, but undetectable in cells at rest ${ }^{(18,20)}$. The Ki-67 index (Ki-67 fraction of the positive nuclear immunohistochemistry) is higher in carcinomas than in hyperplasic glands. Within the group of carcinomas, the Ki-67 index in patients with metastatic 
Table 2

\section{Assessment of data on the label MIB1}

\begin{tabular}{|c|c|c|c|c|c|c|c|}
\hline \multirow{2}{*}{ Data } & \multicolumn{2}{|c|}{ Negative $(n=63)$} & \multicolumn{2}{|c|}{ Positive $(n=37)$} & \multicolumn{2}{|c|}{ Total $(n=100)$} & \multirow[t]{2}{*}{ Value of $p^{*}$} \\
\hline & $n$ & $\%$ & $n$ & $\%$ & $n$ & $\%$ & \\
\hline PSA (ng/dl) & & & & & & & 0.01 \\
\hline$<4$ & 6 & 9.5 & 5 & 13.5 & 11 & 11 & \\
\hline 4 to 9.9 & 51 & 81 & 19 & 51.4 & 70 & 70 & \\
\hline 10 to 19.9 & 4 & 6.3 & 9 & 24.3 & 13 & 13 & \\
\hline$\geq 20$ & 2 & 3.2 & 4 & 10.8 & 6 & 6 & \\
\hline Gleason score & & & & & & & 0.0003 \\
\hline$\leq 6$ & 54 & 85.7 & 18 & 48.7 & 72 & 72 & \\
\hline 7 & 8 & 12.7 & 18 & 48.6 & 26 & 26 & \\
\hline$\geq 8$ & 1 & 1.6 & 1 & 2.7 & 2 & 2 & \\
\hline Pathological stage & & & & & & & 0.001 \\
\hline pTla & 8 & 12.7 & - & - & 8 & 8 & \\
\hline pT2a & 17 & 26.9 & 1 & 2.7 & 18 & 18 & \\
\hline pT2b & 3 & 4.8 & 1 & 2.7 & 4 & 4 & \\
\hline pT2c & 32 & 50.8 & 33 & 89.2 & 65 & 65 & \\
\hline рТЗа & - & - & 1 & 2.7 & 1 & 1 & \\
\hline pT3b & 3 & 4.8 & 1 & 2.7 & 4 & 4 & \\
\hline PSA evolution (control PSA) & & & & & & & 0.174 \\
\hline Cure & 50 & 79.4 & 24 & 64.9 & 74 & 74 & \\
\hline Recidive & 13 & 20.6 & 13 & 35.1 & 26 & 26 & \\
\hline Continents & & & & & & & $0.567^{* *}$ \\
\hline No & 55 & 87.3 & 32 & 86.5 & 87 & 87 & \\
\hline Yes & 8 & 12.7 & 5 & 13.5 & 13 & 13 & \\
\hline Potency & & & & & & & 0.086 \\
\hline Potent with no drugs & 2 & 3.2 & 3 & 8.1 & 5 & 5 & \\
\hline Impotent & 25 & 39.7 & 21 & 56.8 & 46 & 46 & \\
\hline Potent using drugs & 36 & 57.1 & 13 & 35.1 & 49 & 49 & \\
\hline
\end{tabular}

*Chi-square; *Fisher.

disease was significantly higher than in groups without metastases $(2,9,27,36)$. However, the results suggest that the elevation of Ki-67 could define a group with worse prognosis $^{(33)}$.

Bettencourt et al. ${ }^{(4)}$ evaluated the association between rates of proliferation and progression of disease in patients with clinically localized disease, undergoing surgery and found that patients with elevated scores of Ki-67 antigen, had an early progression and a lower disease-free survival at five years when compared to low or negative values of $\mathrm{Ki}-67$. Other authors demonstrated that positive expression of MIB-1 was correlated with higher rates of recurrence ${ }^{(7)}$.
Feneley et al. ${ }^{(15)}$ observed that patients with adenocarcinoma showed rates of Ki-67 higher, with a significantly lower activity in tumors of the transition zone compared with the peripheral zone, which agrees with the less aggressive tumor of the first. The intraepithelial neoplasia showed value of Ki-67 intermediate between benign lesion and adenocarcinoma, showing the progression of proliferation with the change of prostatic parenchyma. Other authors, comparing the different rates of proliferation with tumor aggressiveness, found that the rate of proliferation is higher in normal tissues of patients with presence of adenocarcinoma than in patients 
without cancer, showing that the Ki-67 could also be used for stratification of patients with higher risk of developing neoplasia ${ }^{(2,31)}$.

The studies developed by Aaltomaa et al.(1) showed that the expression of $\mathrm{Ki}-67$ is a potentially useful predictor of survival in prostate adenocarcinoma. Stattin et al. ${ }^{(33)}$ in the multivariate analysis demonstrated the importance of Ki-67 as a prognostic factor associated with the now traditional tumor grade and clinical stage.

Observing patients diagnosed with prostate cancer by transurethral resection and expectant treatment, it was observed that the rate of proliferation was significantly related to tumor grade, clinical stage and presence of metastases. In multivariate analysis, taking into account these variables, the MIB-1 was independent prognostic factor for disease specific survival and overall survival(6). Similar results in relation to Ki-67 observed both the material obtained by prostate biopsy as the material examined after radical prostatectomy showed the same rates of proliferation, demonstrating that the pre-operative examination can be performed to assess tumor aggressiveness ${ }^{(27)}$.

Analyzing some series of patients undergoing surgical treatment, the authors observed that the Gleason score, MIB-1 and perineural invasion were significantly associated to progression, and that the MIB-1 and perineural invasion should be included in combination with traditional factors in all assessments prognostic ${ }^{(32)}$. Other authors as Taftachi et al. ${ }^{(35)}$ described the potential of the metastatic lesion by proliferative activity before the definitive treatment would be valuable to guide appropriate therapeutic decision; they described the increase of Ki-67 in patients who had progression of disease, correlating it to Gleason, stage and recurrence-free survival.

Cowen et al. ${ }^{(11)}$ examined series of patients treated with external radiotherapy for prostate cancer and observed that the MIB-1 remained as independent prognostic factor for biochemical recurrence on multivariate analysis, independent if the diagnosis had been made by biopsy or transurethral resection. There was no correlation between the values of MIB 1 and presence of distant metastasis.

In contrast to these studies, Ojea Calvo et al. ${ }^{(29)}$ suggested that the expression of $\mathrm{Ki}-67$ (3\%) in preoperative biopsies are less effective than the traditional factors such as PSA, the Gleason score and TNM staging in predicting the biochemical progression of cancer after radical prostatectomy.

The expression of MIB-1 in this study was $37 \%$ compared to the overall number of patients. The expression of MIB-1 was statistically significant: on the value of PSA, Gleason score of the surgical and pathological stage, which is equivalent to the data presented in the

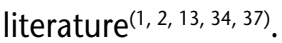

\section{Conclusion}

In this study we concluded that the MIB-1 proved to be a prognostic factor comparable to the classical prognostic factors: PSA, tumor stage and Gleason, helping it to increase the accuracy with respect to the evolution of the disease.

\section{References}

1. AALTOMAA, S. et al. Value of Ki-67 immunolabelling as a prognostic factor in prostate cancer. Eur Urol, v. 159, n. 3, p. 2410-15, 1997.

2. ANANTHANARAYANAN, V. et al. Alterations of proliferation and apoptotic markers in normal and premalignant tissue associated with prostate cancer. BMC Cancer, v. 6, p. 73, p. 1-9, 2006.

3. ARLEN, P. M. et al. Prostate specific antigen working group guidelines on prostate specific antigen doubling time. J Urol, v. 179, p. 2181-6, 2008.

4. BETTENCOURT M. C. et al. Ki-67 expression is a prognostic marker of prostate cancer recurrence after radical prostatectomy. J Urol, v. 156, p. 1064-8, 1998.
5. BILLIS, A. et al. The impact of the 2005 international society of urological pathology consensus conference on standard Gleason grading of prostatic carcinoma in needle biopsies. J Urol, v. 180, p. 548-53, 2008.

6. BORRE, M. et al. Imunohistochemical Bcl-2 and $\mathrm{Ki}-67$ expression predict survival in prostate cancer patients followed expectantly. Prostate Cancer Prostatic Dis, v. 5, p. 268-75, 1998.

7. BUBENDORF, L. et al. Ki-67 labeling index: an independent predictor of progression in prostate cancer treated by radical prostatectomy. J Pathol, v. 178, p. 437-41, 1996.

8. CATTORETTI, G. et al. Monoclonal antibodies against recombinant parts of the $\mathrm{Ki}-67$ antigen (MIB-1 
and MIB-3) detect proliferating cells in microwaveprocessed formalin- fixed paraffin sections. J Pathol, v. 168 , p. 357-63. 1992;

9. CLAUDIO, P. P. et al. Expression of cell-cycle-regulated proteins pRb2/p130, p107, p27kip1, p53, mdm-2 and Ki-67 (MIB-1) in prostatic gland adenocarcinoma. Clin Cancer Res, v. 8, p. 1808-15, 2002.

10. CONCATO, J. et al. Molecular markers and mortality in prostate cancer. BJU Int, v. 100, p. 1259-63, 2007.

11. COWEN, D. et al. Ki-67 staining is an independent correlate of biochemical failure in prostate cancer treated with radiotherapy. Clin Cancer Res, v. 8, p. 1148-54, 2002.

12. DHIR, R. Prostate cancer biobanking. Curr Opin Urol, v. 18, p. 309-14, 2008.

13. DOGANAVSARGIL, B. et al. A comparison of p21 and p27 immunoexpression in benign glands, prostatic intraepithelial neoplasia and prostate adenocarcinoma. BJU Inter, v. 97, p. 644-8, 2006.

14. ERCOLE, B. et al. Outcome following active surveillance of men with localized prostate cancer diagnosed in the prostate specific antigen era. J Urol, v. 180, p. 133641, 2008

15. FENELEY, M. R. et al. Ki-67 in early prostate cancer and associated pathological lesions. J Clin Pathol, v. 49, p. 741-8, 1996.

16. FREEDLAND, S. J.; KRUPSKI, T. L.; MOUL, J. W. Update on outcomes research databases in prostate cancer 2006. Curr Opin Urol, v. 16, p. 168-72, 2006.

17. FREEDLAND, S. J.; MOUL, J. W. Prostate specific antigen recurrence after definitive therapy. J Urol, v. 177, p. 1985-91, 2007.

18. GERDES, J. et al. Immunobiochemical and molecular biologic characterization of the cell proliferationassociated nuclear antigen that is defined by monoclonal antibody Ki-67. Am J Pathol, v. 138, p. 867-73, 1991.

19. GRIGNON, D. J. et al. p53 status and prognosis of locally advanced prostatic adenocarcinoma: a study based on RTOG 8610. J Nat Cancer Inst, v. 89, n. 2, p. 15865, 1997.

20. GUILLAUD, P.; DU MANOIR, S.; SEIGNEURIN, D. Quantification and topographical description of $\mathrm{Ki}$ 67 antibody labeling during the cell cycle of normal fibroblastic (MRC-5) and mammary tumor cell lines (MCF-7). Anal Cell Pathol, v. 1, p. 25-39. 1989.

21. INSTITUTO NACIONAL DE CÂNCER. Estimativa $2008-$ Incidência de câncer no Brasil. Rio de Janeiro: INCA, 2008.

22. JIN, S. p53, autophagy and tumor suppression. Autophagy, v. 1, n. 3, p. 171-3, 2005.

23. KLEIN, E. A. et al. Surgeon experience in strongly associated with biochemical recurrence after racial prostatectomy for all preoperative risk categories. $J$ Urol, v. 179, p. 2212-7, 2008.
24. KUO, N. W.; LIN, H. C.; LEE, H. C. Physician clinical experience and inappropriate prostate specific antigen screening: evidence from an Asian country. J Urol, v. 180, p. 1954-8, 2008.

25. LISKA, J. et al. Prostate tumors-histological classification and molecular aspects of prostate tumorigenesis. Endocrine Regulations, v. 41, p. 45-57, 2007.

26. MOHAPTRA, S. et al. Accumulation of p53 and reductions in XIAP abundance promote the apoptosis of prostate cancer cells. Cancer Res, v. 65, p. 7717-23, 2005.

27. $\mathrm{MUCCl}, \mathrm{N}$. R. et al. Expression of nuclear antigen Ki67 in prostate cancer needle biopsy and radical prostatectomy specimens. J Natl Cancer Inst, v. 92, p. 1941-2, 2000.

28. NEAL, D. E. Can we accurately identify men with low risk prostate cancer? J Urol, v. 180, p. 1217-8, 2008.

29. OJEA CALVO, A. et al. Utilidad de la expresión de Ki67 en las biopsias preoperatorias para predecir la recidiva bioquímica del cáncer de próstata después de la prostatectomia radical. Actas Urol Esp, v. 28: p. 650-60, 2004.

30. RHODES, D. R. et al. Multiplex biomarkers approach for determining risk of prostate-specific antigen-defined recurrence of prostate cancer. J Nat Cancer Inst, v. 95, p 661-8, 2003.

31. RUDOLPH, P. et al. Determination of proliferation activity of prostate cancers by means of nuclear proliferationassociated formalin resistant Ki-S5 antigens. Verh Dtsch Ges Pathol, v. 77, p. 98-102, 1993.

32. SEBO, T. J. et al. Perineural invasion and MIB-1 positivity in addition to Gleason score are significant preoperative predictors of progression after radical retro pubic prostatectomy for prostate cancer. Am J Surg Pathol, v. 26, p. 431-9, 2002.

33. SIMONE, N. L. et al. Pretreatment predictors of death from other causes in men with prostate cancer. J Urol, v. 180, p. 2447-52, 2008.

34. STATTIN, P. et al. Cell proliferation assessed by Ki-67 immunoreactivity on formalin fixed tissues is a predictive factor for survival in prostate cancer. J Urol, v. 157, p. 219-22, 1997.

35. TAFTACHI, R. et al. Proliferating-cell nuclear antigen (PCNA) as an independent prognostic marker in patients after prostatectomy: a comparison of PCNA and Ki-67. BJU Int, v. 95, p. 650-4, 2005.

36. TAMBOLI, P. et al. Comparative analysis of the nuclear proliferative index (Ki-67) in benign prostate, prostatic intraepithelial neoplasia and prostatic carcinoma. Mod Pathol, v. 9, p. 1015-9, 1996.

37. WILT, T. J. et al. Systematic review: comparative effectiveness and harms of treatments for clinically localized prostate cancer. Ann Inter Med, v. 148, n. 6, p. 435-48, 2008. 